\title{
Differences in C-Reactive Protein (CRP) Value Before and After Eradication Therapy of Helicobacter Pilory Gastritis in Children
}

\author{
Siska Octaviani Purba ${ }^{1}$, Supriatmo $^{1}$, Aridamuriany D. Lubis 1 \\ ${ }^{1}$ Departement of Child Health, Faculty of Medicine, Universitas Sumatera Utara, Medan, Indonesia
}

\begin{abstract}
This study aimed to determine the difference CRP values before and after eradication therapy of Helicobacter pylori gastritis in children. A quasi-experimental study with a separate sample pretest-posttest design was carried out by collecting medical records of children aged 2-18 years diagnosed with H. pylori gastritis from October-December 2020. Data on serum CRP levels before and after $\mathrm{H}$. pylori gastritis eradication therapy were collected from patient medical records. Comparison between groups of $\mathrm{H}$. Pylori gastritis before and after eradication therapy was performed using T-dependent/Wilcoxon test. Test the normality using the Saphiro-Wilk test. There were 37 data that met the inclusion and exclusion criteria. The CRP value in children with $\mathrm{H}$. pylori infection $(+)$ before eradication therapy was $19.31 \mathrm{mg} / \mathrm{dL}(10.05-128)$. After giving eradication therapy, the value of CRP decreased to $11.2 \mathrm{mg} / \mathrm{dL}(6.8-30.4)$. Using the Wilcoxon test showed that there was a significant difference in CRP values between before and after eradication therapy $(p<0.001)$. There was a significant difference in CRP values between before and after $\mathrm{H}$. pylori eradication therapy in children.
\end{abstract}

Keywords: h. pylori, c-reactive protein, eradication therapy

\section{Introduction}

Helicobacter pylori (H. pylori) infection usually begins in childhood, generally before the age of 5 years, then continues throughout life, and causes severe diseases such as gastritis, gastric ulcers, gastric carcinoma, and duodenal ulcers in adulthood. H. pylori has been recognized as a gastric pathogen infecting more than half of the world's population (Razavi et al,2015). This infection causes a low but chronic inflammatory response in the gastric and duodenal mucosa, which can last a lifetime if left untreated. Early diagnosis and treatment can prevent H. pylori-associated complications (Yang et al, 2019).

Helicobacter pylori commonly colonizes the human gastric mucosa. It is estimated that $50 \%$ of the world's population may be infected, and the prevalence is higher in the population of low-income countries, ranging from $65 \%$ in adults from Thailand and Ethiopia, to $85 \%$ in mothers in Bangladesh. The prevalence of $\mathrm{H}$. pylori in Bangladesh ranges from $47 \%$ in children under 2 years of age, $60 \%$ in children less than 5 years, to 93\% prevalence in children under 15 years of age (Buerkli et al, 2000).

The characteristics of $\mathrm{H}$ pylori infection in children are different from adults. Most children infected with $\mathrm{H}$ pylori remain asymptomatic, but develop chronic superficial gastritis, and a small percentage develop duodenal ulcers in late childhood or adolescence. Lymphoma of the lymphoid mucosal tissue and gastric ulcer are rare in children. Stomach cancer (adenocarcinoma) mainly develops in adults (Dror etal, 2016).

C-reactive protein (CRP) is an acute-phase protein, originally named after its ability to precipitate cpolysaccharides from Streptococcus pneumoniae. The acute phase response consists of non-specific physiological responses and biochemical responses to most forms of tissue damage, infection, and inflammation. It is now widely used as a recognized marker for diagnosing and monitoring infections, especially in secondary health care. But now it is also increasingly being used by doctors in primary health care in identifying patients who may not respond to antibiotics. Thus, CRP has great potential as a useful tool to promote the correct use of antibiotics (Cals et al, 2018)

In recent guidelines, the recommended pediatric protocol for $\mathrm{H}$ pylori eradication should consist of a combination of a proton pump inhibitor (PPI) and two high-dose antimicrobial agents, prescribed for 2 weeks. Treatment success should be more than $90 \%$ for each protocol analysis in preventing secondary antimicrobial resistance, reducing expensive procedures, and risky procedures required in advanced treatment. This number is rarely described in pediatric studies because of the high rate of antibiotic resistance against $\mathrm{H}$ pylori. The 
prevalence of H. pylori-resistant antibiotics between countries and is usually explained by different exposures to antibiotics in each population (Misak et al, 2019)

\section{Methods}

2.1. Subjects and Methods

This study was a quasi-experimental study with a separate sample pretest-posttest design. This study aimed to determine the difference in CRP values before and after H. pylori eradication therapy for gastritis in children, by taking medical record data. The subject of the study was the medical records of children aged 218 years who was diagnosed with $\mathrm{H}$. pylori gastritis. Inclusion criteria were children between two and eighteen years old, confirmed $\mathrm{H}$. pylori gastritis, that has been given eradication therapy after being diagnosed with $\mathrm{H}$. pylori gastritis. Patient with other infection which have no relationship to gastritis, and abdominal bleeding were excluded.

Demographic data were collected in gender, education level of patients and parents, socioeconomic level, race, and clinical symptoms. Serum CRP levels were collected from patient medical records before and after H. pylori eradication therapy for gastritis. Examination of serum CRP levels was carried out at H. Adam Malik Hospital Medan, Universitas Sumatera Utara Hospital, and other hospital with the same method using the Enzyme Linked Immunosorbent Assay (ELISA) method.

\subsection{Research Ethics}

This study was approved by the Ethics Committee of the Faculty of Medicine, Universitas Sumatera Utara/Haji Adam Malik General Hospital, Medan No: 813/KEP/USU/2020.

2.3. Statisticalanalysis

Data was Statisticalanalysis using SPSS version 23. All data from the sample research were recapitulated and displayed in the form of general (descriptive) characteristics first. Hypothesis testing for the comparison of two paired groups (between the H. Pylori gastritis group before and after eradication therapy) was performed using a paired T-test, and if the data were not normally distributed, the Wilcoxon test was used. Test the normality of the data using the Saphiro-Wilk test. The significance of the statistical test results was determined based on the $\mathrm{p}$ value $<0.05$ with a $95 \%$ confidence interval.

\section{Results}

There were 37 children that met inklusion and exclusion criterias. From the 37 children with H. pylori (+), 12 children $(32.4 \%)$ were male and 25 (67.6\%) were female. The mean age of the children was 11.56 years $(\mathrm{SD}=3.64$ years). Based on ethnicity, the dominant tribe is Bataknese which is 17 children (54.9\%). The majority of the subjects came from families with good socioeconomic levels totaling 30 children (81.1\%). The education of the children's subjects was mostly elementary school, amounting to 17 people (45.9\%), while the subject's father and mother with the highest education level were universities. The father's occupation of the most subjects is 18 people (48.9\%) and the mother's work is mostly employees and civil servants with the same number of 9 people (24.3\%). The mean weight and height in the group of children with H. pylori (+) were 35.10 $\mathrm{kg}$ and $135.89 \mathrm{~cm}$. A total of 25 children $(67.6 \%)$ had a family history of gastritis. The most clinical symptoms were abdominal pain as many as 20 people $(54.1 \%)$.

Table 3.1. Demographic characteristic subject

\section{Characteristic}

$$
\mathbf{n}=\mathbf{3 7}
$$

\begin{tabular}{lc}
\hline Sex, $\mathrm{n}(\%)$ & $12(32.4)$ \\
Boy & $25(67.6)$ \\
Girl & $11.56(3.64)$ \\
Age, n (\%), mean (SD), tahun & \\
Ethnicity, n (\%) & $6(16.2)$ \\
Aceh & $17(45.9)$ \\
Batak & $6(16.2)$ \\
Jawa & $1(2.7)$ \\
Melayu & $4(10.8)$ \\
Minang & \\
\hline
\end{tabular}




\begin{tabular}{|c|c|}
\hline Papua & $2(5.4)$ \\
\hline Tionghoa & $1(2.7)$ \\
\hline \multicolumn{2}{|l|}{ Economic status, n (\%) } \\
\hline Poor & $7(18.9)$ \\
\hline Good & $30(81.1)$ \\
\hline \multicolumn{2}{|l|}{ Child's education, n (\%) } \\
\hline Preschool & $1(2.7)$ \\
\hline Primary school & $17(45.9)$ \\
\hline Junior high school & $10(27)$ \\
\hline Senior high school & 7 (18.9) \\
\hline College & $2(5.4)$ \\
\hline \multicolumn{2}{|l|}{ Father's education, n (\%) } \\
\hline Senior high school & $8(21.6)$ \\
\hline College & $29(78.4)$ \\
\hline \multicolumn{2}{|l|}{ Pendidikan Ibu, n (\%) } \\
\hline Senior high school & $5(13.5)$ \\
\hline College & $32(86.5)$ \\
\hline \multicolumn{2}{|l|}{ Father,s occupation, n (\%) } \\
\hline Employee & $18(48.6)$ \\
\hline Farmer & $4(10.8)$ \\
\hline Government employee & $4(10.8)$ \\
\hline Military/Police & $2(5.4)$ \\
\hline Enterpreneur & $9(24.3)$ \\
\hline \multicolumn{2}{|l|}{ Mother's occupation, n (\%) } \\
\hline Employee & $9(24.3)$ \\
\hline Farmer & $6(16.2)$ \\
\hline Government employee & $9(24.3)$ \\
\hline Enterpreneur & $7(18.9)$ \\
\hline Housewife & $6(16.2)$ \\
\hline Body weight, mean (SD), kg & $35.3(11.48)$ \\
\hline Body height, mean (SD), cm & $135.89(17.63)$ \\
\hline
\end{tabular}

Table 3.2. Clinical characteristic

\begin{tabular}{lc}
\hline \multicolumn{1}{c}{ Clinical characteristic } & $\mathbf{n}=\mathbf{3 7}$ \\
\hline Family history, n (\%) & $25(67.6)$ \\
Yes & $12(32.4)$ \\
No & \\
Simptom, n (\%) & $11(29.7)$ \\
Vomit & $6(16.2)$ \\
Bloody vomit & $20(54.1)$ \\
Abdominal pain & \\
\hline
\end{tabular}

The results of the study showed that the CRP value in children with H. pylori infection (+) before eradication therapy was $19.31 \mathrm{mg} / \mathrm{dL}(10.05-128 \mathrm{mg} / \mathrm{dL})$. After giving eradication therapy, it appears that there is a decrease in the value of CRP to $11.2 \mathrm{mg} / \mathrm{dL}(6.8-30.4 \mathrm{mg} / \mathrm{dL})$. Using the Wilcoxon test showed that there was a significant difference in CRP values between before and after eradication therapy $(\mathrm{p}<0.001)$.

Table 3.3 Diffrences CRP values based on H. pylori infection

\begin{tabular}{|c|c|c|c|}
\hline \multirow{2}{*}{$\begin{array}{c}\text { CRP } \\
(\mathrm{mg} / \mathrm{dL})\end{array}$} & \multicolumn{2}{|c|}{ Eradication Therapy } & \multirow{2}{*}{$\mathbf{p}^{\mathbf{a}}$} \\
\hline & Pre Therapy & Post Therapy & \\
\hline Median & 19.32 & 11.2 & 0.000 \\
\hline $\operatorname{Min}-\max$ & $10.05-128$ & $6.8-30.40$ & \\
\hline
\end{tabular}

${ }^{\mathrm{a}}$ Wilcoxon 


\section{Discussion}

The prevalence of $\mathrm{H}$. pylori infection varies greatly depending on geographic region, age, race, and socioeconomic status. Transmission of $\mathrm{H}$. pylori tends to be faster in developing countries than in developed countries. The study stated that H. pylori infection was highest starting in early childhood (Brown et al, 2000). In this study, it was stated that $\mathrm{H}$. pylori gastritis was most common in girls $(67.6 \%)$. This is consistent with a study in Uganda which showed that H. pylori infection was higher in women than men, which is $53.3 \%$ (Aguemon et al, 2005). The study in Benines also showed that H. pylori infection was more common in women (76.2\%). However, it was also stated that there was no relationship between gender and H. pylori infection (Nguyen dkk, 2017). In contrast to the study in Vietnam which showed that H. pylori seropositivity was highest in boys, which was around $46.1 \%$ (Aitila et al, 2019).

In this study, the mean age of children suffering from H. pylori gastritis was 11.56 years. This is consistent with a study in Nigeria which showed that H. pylori infection was higher at the age of 6-12 years. It is also mentioned that children aged 6-12 years have a twice greater risk of H. pylori infection than children 1-5 years (Daniyan et al,2020). Research in Turkey showed H. pylori infection was higher in the group of children aged 11-15 years (70.76\%). This study also reported that $\mathrm{H}$. pylori infection had a significant difference based on age, and tended to increase with age (Ceylan et al, 2007). Research in Uganda showed H. pylori infection was high in children aged 1-5 years, which is $42.8 \%$ (Aguemon et al, 2005). Research in Vietnam showed H. pylori infection was higher in children aged 15-18 years, about 45.9\% (Aitila et al, 2019). H. pylori colonization begins early in life, during infancy the infection is limited to family members and caregivers. Exposure increases with age, which may explain the higher infection rates in children starting school. Infection rates can be higher in school children with poor sanitation environments, and lack of clean water sources (Brown et al, 2000).

Based on ethnicity, in this study, the majority of children were Bataknese (54.9\%). It is stated that the influence of ethnicity or race on H. pylori infection has been widely studied. Research in Pontianak showed that the prevalence of $\mathrm{H}$. pylori infection in the Chinese was $14.3 \%$ higher than the Dayak (Uwan et al, 2016). Research in five major islands in Indonesia showed that ethnic Papuans had the highest prevalence of H. pylori infection (42.9\%). And the Batak ethnicity ranks second highest at $40 \%$. It is stated that ethnic Papuanese have a high rate of $\mathrm{H}$. pylori infection because they have a strong tradition and live in mountainous areas (Syam et al, 2015).

In this study, the most dominant clinical symptom was abdominal pain, which was $54.1 \%$. Abdominal pain is the main complaint of disorders of the digestive tract system in preschool and school-aged children with a prevalence of around $10 \%$ (Hegar et al, 2000). Research in Turkey states that the main complaint in children with H. pylori infection is recurrent abdominal pain, which is $75.3 \%$ (Ceylan et al, 2007).

C-reactive protein (CRP) is an acute phase protein that is expressed and secreted by the liver. In response to tissue injury or infection, plasma CRP concentrations can increase rapidly within 48 hours in response to tissue damage and infection. In addition, CRP concentrations also increase in chronic inflammatory diseases, including autoimmune and cardiovascular diseases (Yao et al, 2019). In this study, there were differences in CRP values before and after eradication therapy, namely the CRP value before eradication therapy was $19.32 \mathrm{mg} / \mathrm{dL}(10.05-128 \mathrm{mg} / \mathrm{dL})$, and the CRP value after eradication therapy was $11.2 \mathrm{mg} / \mathrm{dL}$ (6.8-30.4 mg/dL). Using the Wilcoxon test showed that the CRP values were significantly different between before and after eradication therapy. This is in accordance with the American study of $\mathrm{H}$. pylori infection that triggers an increase in CRP in African Americans with obesity. This study showed a significant decrease in CRP values in the obese group who had successfully eradicated after receiving therapy. Meanwhile, in the group that did not experience eradication after surgery, the CRP value did not decrease (Siddiqui et al, 2009).

A study in Japan stated that the CRP value was positively associated with anti-H. pylori antibodies in seropositive patients.28 A study in Turkey stated that the CRP value in H. pylori infection decreased significantly after being given therapy. The mean CRP values at the time of admission, 24 hours of treatment and after therapy were $1.00 ; 1.15$; and $0.95 \mathrm{mg} / \mathrm{dL}$. However, there was no significant difference between the groups with H. pylori infection and without H. pylori infection. Unlike other Gram-negative bacteria (eg E. Coli and Salmonella), the lipid molecule A H. pylori has no phosphate, and consists of four carbon bonds and an amino acid, so the number of carbons in the molecule increases. This results in a weak induction of the release of proinflammatory cytokines, particularly IL 6 and IL 8 from monocytes and neutrophils (Saribas et al, 2004). 
In contrast to the Brazilian study, it was stated that there was no association between CRP levels and H. pylori infection in patients with functional dyspepsia, especially those who were Cag A positive (Andreolla et al, 2016). Research in Korea stated that H. pylori seropositivity was not associated with CRP levels. This study also mentions the possibility of this happening because this study has considered confounding factors that can affect the results of the study, which were not found in other studies (Kim et al, 2018).

The advantage of this study is that the examination of Helicobacter Pylori on the subject is endoscopic examination/CLO test which is the gold standard for examination of H. pylori gastritis. There are few studies on the relationship between CRP values before and after eradication therapy in children, so this is one of the strengths of this study. The limitation of this study is that there is no comparison of CRP values with other markers of infection in the blood. Researchers think that further research is needed to assess the comparison of CRP levels with other infection markers in assessing the success of $\mathrm{H}$. pylori eradication therapy in children.

\section{Conclusion}

There were significant differences in CRP values between before and after H. pylori eradication therapy in children.

\section{Acknowledgements}

The author thanks to all clinical staffs of Pediatric Gastroenterohepatology Usiversitas Sumatera Utara, who were involved and contributed to the completion of this study.

\section{References}

Aguemon BD, Struelens MJ, Massougbodji A, Ouendo EM, 2005. Prevalence and risk-factors for Helicobacter pylori infection in urban and rural Beninese populations. Clin Microbiol 11, p 611-7.

Aitila P, Mutyaba M, Okeny S, Kasule MN, Kasule R, Ssedyabane F, et al, 2019. Prevalence and risk factors of Helicobacter pylori Infection among children aged 1 to 15 years at Holy Innocents, children's hospital, Mbarara, South Western Uganda. J Trop Med.

Andreolla HF, de Bona LR, Sander GB, Mazzoleni LE, Tavares RG, Prolla JC, 2016. Lack of association between Helicobacter pylori's virulance and increased serum C-reactive protein levels in functional dyspeptic patient. Arq Gastroenterol 53, p49-53

Brown LM, 2000. Helicobacter pylori: epidemiology and routes of transmission. Epidemiol Rev 22, p283-96.

Buerkli S, Ndiaye NF, Cercamondi CL, Aerbeli IH, Moretti D, Zimmermann MB, 2019. Asymptomatic Helicobacter Pylori infection in preschool children and young women does not predict iron bioavailability from iron-fortified foods. Nutrients 11 , p2093.

Cals JWL, Ebell MH, 2018. C-reactive protein: guiding antibiotic prescribing decisions at the point of care. Editorials. Br J Gen, p112-3.

Ceylan A, Kırımi E, Tuncer O, Türkdoğan K, Arıyuca S, Ceylan N, 2007. Prevalence of Helicobacter pylori in children and their family members in a district in Turkey. J Health Popul Nutr.25, p422-7.

Daniyan OW, Ibe CB, Ezeonu TC, Anyanwu OU, Ezeanosike OB, Omeje KN, 2020. Seroprevalence and Risk Factors of Helicobacter Pylori Infection Among Children in South-East Nigeria. J Gastrol Hepatol Res, p9.

Dror G, Muhsen K, 2016. Helicobacter pylori infection and children's growth: an overview. JPGN 6, pe48-e59.

Hegar B, 2000. Infeksi Helicobacter Pylori pada anak. Sari Pediatrik 2, p82-9.

Kim TJ, Pyo JH, Lee H, Baek SY, Ahn SH, Min YW, et al, 2018. Lack of association between Helicobacter pylori infection and various markers of systemic inflammation in asymptomatic adults. Korean J Gastroenterol 7, p21-7.

Misak Z, Hjosak I, Homan M 2019. Review: Helicobacter pylori in pediatrics. Helicobacter 24, pe12639.

Nguyen TVH, Phan TTB, Nguyen VB, Hoang TTH, Anh TL, Nguyen TTM, et al, 2017. Prevalence and risk factors of Helicobacter pylori in Muong children in Vietnam. Ann Clin Lab Res, p5.

Razavi A, Bagheri N, Dehkordi FA, Shirzad M, Rahimian G, Kopael MR, et al, 2015. Comparative immune response in children and adults with H. pylori infection. J Immunol Res, p1-6. 
Saribas S, Kocazeybek B, Aslan M, Altun S, Seyhun Y, Oner YA, et al, 2004. Do procalcitonin and C-reactive protein levels have a place in the diagnosis and follow-up of Helicobacter pylori infections? J Med Microbiol 53, p639-44.

Siddiqui NR, Garvey WT, Khaled MA, 2009. H. pylori-Induced higher C-Reactive Protein in obese African Americans. Artery Res 3, p3942.

Syam AF, Miftahussurur M, Maknum D, Nusi IA, Zain LH, Zulkhairi, 2015. Risk factors and prevalence of Helicobacter pylori in five largest islands of Indonesia: a preliminary study. Plos one.

Uwan WB, Syam AF, Lesmana CRA, Rumende CM, 2016. Perbedaan Prevalensi Infeksi Helicobacter pylori antara Etnis Tionghoa dan Dayak dengan Sindrom Dispepsia. J Penyakit Dalam Indonesia 3, p1.

Yang L, Zhang J, Xu J, Wei X, Yang J, Liu Y, et al, 2019. Helicobacter pylori infection aggravates dysbiosis of gut microbiome in children with gastritis. Front Cell Infect Microbiol, p375.

Yao ZY, Zhang Y, Wu HB, 2019. Regulation of C-reactive protein conformation in inflammation. Inflamm Res. 